\title{
Raphaël INGELBIEN, Irish Cultures of Travel: Writing on the Continent, 1829-1914, London, Palgrave Macmillan, 2016
}

\section{Michelle Milan}

\section{(2) OpenEdition \\ 1 Journals}

\section{Electronic version}

URL: http://journals.openedition.org/etudesirlandaises/5413

DOI: 10.4000/etudesirlandaises.5413

ISSN: 2259-8863

\section{Publisher}

Presses universitaires de Caen

\section{Printed version}

Date of publication: 29 November 2017

Number of pages: 167-168

ISBN: 978-2-7535-7388-8

ISSN: 0183-973X

\section{Electronic reference}

Michelle Milan, «Raphaël Ingelbien, Irish Cultures of Travel: Writing on the Continent, 1829-1914, London, Palgrave Macmillan, 2016 », Études irlandaises [Online], 42-2 | 2017, Online since 29 November 2017, connection on 24 September 2020. URL : http://journals.openedition.org/etudesirlandaises/ 5413 ; DOI : https://doi.org/10.4000/etudesirlandaises.5413

\section{(c) (i) (8)}

Études irlandaises est mise à disposition selon les termes de la Licence Creative Commons Attribution - Pas d'Utilisation Commerciale - Partage dans les Mêmes Conditions 4.0 International. 
diffuse and syncretic spirituality or to the replacement of one transcendence by another, the market of neoliberal materialism.

Among its many qualities (expertise and diversity of the contributors, construction of the sequence of chapters), this volume distinguishes itself by its dispassionate tone. It succeeds in avoiding the pro- or anti-Catholic stance. Joe Cleary invites the Irish Catholic world to move from "dead certainties" to "intelligent questions." This book will definitely contribute enormously to accomplishing that transition.

Alexandra SLABY

Raphaël Ingelbien, Irish Cultures of Travel: Writing on the Continent, 1829-1914, London, Palgrave Macmillan, 2016, Ix + 252 p., ISBN 978-1-137-56784-0 (ebook) \$69.99, ISBN 978-1-137-56783-3 (hardcover) \$95.00.

The publication of Raphäl Ingelbien's Irish Cultures of Travel is symptomatic of a growing scholarship on the history of Irish travel abroad and Irish travel writing. Indeed, the book breaks new ground in that it represents the first attempt to chart Irish travel out of Ireland in the long nineteenth century. To date, most of the research in the field has been devoted to travel and tourism in Ireland. In a century marked by massive emigration out of Ireland, it is also understandable that Irish tourism abroad in the period has been overshadowed. The book's timeline, set between Catholic Emancipation in 1829 and the breakout of World War I, allows the author to investigate the travelling cultures of the Victorian and Edwardian Irish middle classes, including a growing Catholic middle class, in a more systematic way than has ever been done before. The term "cultures of travel" is very apt inasmuch as the Irish travelled abroad for a variety of reasons and with diverse experiences and backgrounds.

The book quotes from a wide range of sources, including many anonymous articles in the contemporary press. It also includes the writings of, for example, Mathew O'Conor, Thomas Davis and Selina Martin. Except for an excursion into James Joyce's 'The Dead', the book shifts attention away from canonical literature, turning the spotlight on texts that provide "evidence of remarkable cultural trends" (p. 12). The "reader-oriented approach" claimed in the book is not, however, a reader-response approach as such; rather, the focus is on public discourse. Public discourse on Irish travel shows that national, political and religious identities were often at stake. Such discourse would convey, for example, utilitarian agendas, anti-modern ideas and/or cultural nationalist programmes. Among 
the topics covered is the antiquarian or historically-minded search for Irish footprints on the Continent (Fontenoy, Montorio, etc.). In an era when women's sphere was thought to be domestic, their travel opportunities were accordingly more limited. Yet, Irish women such as Margaret Stokes or "Mrs. T. Mitchell" provide significant examples of independent female travel. The fifth chapter is arguably one of the most stimulating parts of the study in terms of its firm focus and the material that it analyses. It investigates the rise of Irish pilgrimages to Catholic centres such as Lourdes, Oberammergau and Rome, highlighting the pilgrims' increased affiliation to a "universal" Roman Catholic Church, and examining Irish Protestant responses to these Catholic spaces. The role played by Thomas Cook's tourist agency is also significant. Accordingly, Chapter 3 is a welcome attempt to focus on the material conditions for travel and for the dissemination of travel writing, charting some of the sociological, infrastructural and technological changes that contributed to the development of Irish tourism abroad - most notably increased transport facilities and the rise of steam power.

As the author admits, such a broad undertaking necessarily means that the book cannot provide an exhaustive treatment of the topic. Many destinations, travellers, texts and themes have not been included. The focus is limited to a number of European sites, but one important debate about travel occurred regardless of specific destinations: a major motif in the discourse on Irish travel was the tension between home and abroad, and the encouragement to "see Ireland first". It is in this light, and against the background of a developing Irish tourist industry (notably in the rural, Gaelic-speaking west of Ireland) that Chapter 8 revisits Joyce's "The Dead" and the confrontation between Gabriel Conroy and Miss Ivors. Travel and discourse about travel bring about questions of identity - and in this case, a complex web of identities - which is really the main thread that ties the book together. No doubt it makes an important contribution to the fields of Irish studies and studies of European travel.

Michelle MiLan

Vincent Morley, The Popular Mind in Eighteenth-century Ireland, Cork University Press, 2017, ix +362 p, ISBN 978-1-7820-5208-1.

Vincent Morley est un historien irlandais, spécialiste du XvIII ${ }^{\mathrm{e}}$ siècle -the «long $18^{\text {th }}$ century » de 1691 à 1830 , depuis la conquête de l'Irlande par Guillaume III d'Orange jusqu'aux débuts de la campagne pour l'abrogation de l'Acte d'Union menée par Daniel O’Connell. Néanmoins l'ouvrage de Morley ne se donne pas 